\title{
Fagleg autonomi krev fagleg samarbeid
}

Lovgjevinga her i landet, både helsepersonelloven og den nye loven om kommunale helse- og omsorgstenester, legg stor vekt på at den einskilde legen både vil og kan drive verksemda si fagleg forsvarleg. Så seint som i juni 2011 viste ein samla helse- og omsorgskomité på Stortinget tillit til at helsepersonell kan stå ansvarleg for eiga verksemd også i framtida ved å seie: «Komiteen deler den oppfatning at det er behov for å understreke den enkeltes ansvar for å yte forsvarlige og gode tjenester» (1). Til grunn for denne tilliten ligg ei tru på at både legar og anna helsepersonell vil vere i stand å utvikle sin eigen praksis «i takt med kunnskapen innenfor helseog omsorgsfagene», for å nytte komiteen sine eigne ord.

Dette kan godt lesast som ei kraftig oppmoding til legane om å halde orden i eigne rekkjer. Det er ikkje fritt fram for kvar einskild lege å fare fagleg fram som ho eller han ønskjer. Legen må jamt orientere seg inn mot det som er allment gangbart innanfor den greina av medisinen som vedkommande tilhøyrer. Ikkje berre i Noreg er det slik. Den svenske hälso- och sjukvårdslagen har denne utsegna om slik praksis: «i överensstämmelse med vetenskap och beprövad erfarenhet» (2). Ei slik utsegn tyder at pasienten skal kunne vente seg ei undersøking og behandling som har grunnlaget sitt i noko meir enn oppfatningar og røynsler til den einskilde legen. Kravet inneber også at ein bør kunne skilje god praksis frå dårleg praksis.

I dette nummeret av Tidsskriftet blir det publisert ein artikkel som påviser store skilnader mellom den praksisen ulike allmennlegar fører når det gjeld tilvising av pasientar til spesialisthelsetenesta (3). Forfattarane har teke utgangspunkt i den offentlege statistikken frå Norsk pasientregister som syner store geografiske variasjonar i bruken av spesialisthelsetenesta (4). Dei har så grave djupare i materialet og sett på data om tilvisingspraksis frå allmennlegane, som alle er fastlegar, i tre kommunar i Sogn og Fjordane fylke.

Forfattarane påviser at eit høgt forbruk av elektive døgnopphald fører til eit høgt nivå for innleggingar i sjukehusa i fylket. Dei påviser vidare at det er store skilnader i tilvisingspraksis til poliklinikkane i spesialisthelsetenesta både mellom dei tre kommunane som dei har sett nærare på, og mellom dei ulike einskildlegane i desse kommunane. Trass i ei rekkje metodiske utfordringar, argumenterer forfattarane godt for at særdraga ved tenestene i fylket meir kan forklårast av ulike lokale og personlege tilvisingskulturar enn av variasjonar i behovet for spesialisthelsetenester blant folket. Dette er ein bodskap som det samla medisinske fagmiljøet i kvar kommune og innanfor kvart einskild helseføretak, ikkje berre i Sogn og Fjordane, må ta på det djupaste alvor i tida som kjem.

Allmennlegen har viktige oppgåver med å sikre likeverdig tilgang til spesialisthelsetenestene. For å oppnå viktige politiske mål, hevdar Olav Helge Førde [rettet] og medarbeidarar at ein må kunne stille faglegeg krav som vil innskrenke den faglege autonomien til den einskilde allmennlegen (3). Det er sjølvsagt vanskeleg å argumentere mot dette. Men det kan vere fruktbart for både den einskilde allmennlegen og for dei faglege fellesskapa å sjå dette på ein litt annan måte. Allmennlegen har eigentleg aldri vore autonom i den forstand at vedkommande har kunna handle heilt fritt og ubunde. Alle legar er bundne på mange måtar, uavhengig av faglege retningsliner frå styremaktene. Som nemnd innleiingsvis er legen bunden av det som er fagleg forsvarleg, og ein er bunden av pasienten sine eigne ønskje og val.
Rettleiingsmateriale og faglege føringar frå sentrale styremakter, slik som til dømes Helsedirektoratet og Statens lækjemiddelverk, kan vere trygt og nyttig å følje, men er slett ikkje nok for å sikre ein meir heilskapleg praksis mellom allmennlegane. Korkje vedtak i Stortinget eller dokument frå styremaktene kan erstatte dei faglege fellesskapa. Det er desse som bør vere dei viktigaste kjeldene til fagleg normering i det daglege. Der er i slike fellesskap at ein bør lese retningsliner gjevne frå sentralt hald i lys av oppdatert fagleg kunnskap, og sørgje for at dei blir sette i verk. Det er liten grunn til å tru at sjølv ganske detaljerte rundskriv vil medføre særleg sterk normering dersom dei berre blir tolka av den einskilde legen åleine på kontoret sitt.

I stortingsmeldinga om samhandlingsreforma har portopnarfunksjonen til fastlegen og dei meir logistikkprega sidene av allmennlegeverksemda fătt brei omtale (5). I det praktiske arbeidet med gjennomføringa av denne reforma, og med innføringa av ny helseog omsorgstenestelov, bør merksemda minst like mykje vere retta mot dei medisinske utfordringane i grenseflata mellom primærog spesialisthelsetenesta. Dersom ein skal lukkast i dette arbeidet, må allmennlegane og sjukehuslegane sjølve finne fram til varige og tillitsskapande samarbeidsformer som byggjer på solid medisinsk kunnskap. Utan stabile strukturar for fagleg samarbeid, vil det vere vanskeleg å finne fram til forsvarleg praksis i grenseflata mellom desse to medisinske tiltaksnivåa. Ved å byggje den lokale samhandlinga på sentralt gjevne retningsliner, trur eg at slike retningsliner kan styrkje den reelle faglege autonomien ved å skape ei trygg plattform for profesjonell handling. Ei slik trygg fagleg plattform må alle legar ha for ikkje å vere eit passivt offer for skiftande vêr og vind mellom politiske reformer og pasientars ulike ønskje.

Då kan rolla til allmennlegen i forholdet til spesialisthelsetenesta ikkje berre få preg av å vere ein portopnar som skal prioritere rett, men ha vel så mykje preg av å vere ein kvalitetssikrar som kan stå som garantist for at den einskilde pasient blir vurdert og behandla i samsvar med oppdaterte krav til fagleg forsvarleg verksemd nett slik som Stortinget ventar seg.

\section{Geir Sverre Braut \\ gsb@helsetilsynet.no \\ Statens helsetilsyn \\ Høgskolen Stord/Haugesund}

Geir Sverre Braut (f. 1955) er assisterande direktør i Statens helsetilsyn og førstelektor ved Høgskolen Stord/Haugesund.

Oppgitte interessekonflikter: Embetsmann.

\section{Litteratur}

1. Helse- og omsorgskomiteen. Innst. 424 L. (2020-2011). Innstilling fra helseog omsorgskomiteen om lov om kommunale helse- og omsorgstjenester m.m. (helse- og omsorgstienesteloven). (Prop. 91 L (2010-2011). Oslo: Stortinget, 2011.

2. Hälso- och sjukvårdslag (1982: 763). Stockholm: Regeringskansliet, 1982.

3. Førde $\mathrm{OH}$, Breidablik H-J, Øgar P. Truar skilnadene i tilvisingsratar måle om likeverdige helsetenester? Tidsskr Nor Legeforen 2011; 131: 1878-81.

4. Norsk pasientregister. Aktivitetsdata for somatisk spesialisthelsetjeneste 2010. IS-1904. Oslo: Helsedirektoratet, 2011

5. St.meld. nr. 47 (2008-2009). Samhandlingsreformen. Oslo: Helse- og omsorgs departementet, 2009

Engelsk oversettelse av hele artikkelen på www.tidsskriftet.no 